\title{
IMPLICATIONS OF CHILD CUSTODY IN ISLAMIC FAMIILY LAW: A CASE STUDY OF CUSTOMARY COURTS IN OYO STATE, NIGERIA
}

\author{
Aminullahi Adetoro Yusuff*
}

\begin{abstract}
Studies carried out to investigate the immediate and remote causes of marital discord arising from many of the customary courts in Oyo State, Nigeria, revealed that out of 127 divorce-related cases, 87 involved Muslim couples. Out of this number, 53 were linked to custody of children (al-hadanah which is a regulation that has to do with whom should a child stay after the dissolution of marriage for his/her proper nourishment, protection and wellness in the process of upbringing). This issue has led to many serious disputes among Muslim couples and their families in many localities of the state so much that, in many cases, it has led to street fights, vandalisation of property, civil unrest and legal battles. To worsen the situation, without recourse to Islamic marital jurisprudence, judgments are passed in the customary courts in favour of either of the couples. Therefore, the aftermath of the court verdict does not end this debacle in some cases, with to snowballing into spiritual fighting, where family members of the couples bewitch one another to take custody of the children. This problem is not new but it has risen to an alarming proportion these days. It is against this backdrop that an attempt is made in this paper to examine the practice of child custody after divorce or separation in Islam with a view to laying to rest the series of crises associated with the determination of who is to take care of children after divorce and to bring to people's awareness the shariah rulings on child custody. The paper concludes that al-hadanah is a measure in disguise to safeguard indiscriminate severance of the cord of marriage and that Islam, through its system of law, has provided practical and lasting solutions to every imagined and real problem of man and that adoption of children in its various forms and types is forbidden in Islam.
\end{abstract}

Keywords: Adoption, al-hadanah, child custody, customary court, marital jurisprudence, shariah.

\section{Introduction}

Islam is a complete way of life that legislates on every aspect of man's life and provides measures that safeguard such legislations. Marriage is one of the enactments of Islam which is held in high esteem and elevated far and above 
other contracts which people venture into. In the words of the glorious Qur'an, an enviable position of honour has been accorded to the marriage contract and, therefore, it is regarded as 'a solid and powerful undertaking'. ${ }^{1}$ To this end, the Qur'an declares:

And how could you take it when you have gone in unto each other, and they have taken from you a solemn covenant. (Q.4: 21). ${ }^{2}$

Ghaanim reiterates that the marriage contract unites the couple with the bond of love. Although they are two separate individuals, as a couple they now count as one as each resembles the other and carries each other's dreams, hopes and pains. ${ }^{3}$ Among the chief aims of marriage is the establishment of the best environment for the partners to benefit from each other by sharing happiness, support and intimacy. Attaining to this requires the fear of Allah and establishment of a relationship based on sincerity and faithfulness. These would bring about mutual happiness, tranquility, comfort, solace, love and mercy which will permeate permanently among them and thereafter extended to the children, from there to the in-laws and to the community at large. ${ }^{4}$

However, the shariah according to Doi, does not in any way preclude the possibility of a time in a couple's life when it becomes evidently impossible for them to tolerate one another and live together as spouses. In the event that wise counsels and thought-provoking sermons do not help, rather than enduring in a marriage towards ruin and discomfort, Islam permits amicable separation between the parties. This differs from what obtains in some religions where divorce is not permitted and the couple will have to linger under the pretense of hopes, enjoyments and merry-making. ${ }^{5}$

However, Islam recommends reconciliation between spouses as a measure to safeguard the relationship from being severed. But, if in the long run it becomes crystal clear that the couple can no longer co-exist in peace and tranquility, they are not chained together to a painful and agonising end; Islam recommends mutual divorce for both. The fall-outs from divorce include: remorse-elation, waiting period, maintenance during the waiting period, custody of children, bride price settlement and re-marriage. ${ }^{6}$ Without doubt, children are the immediate victims of divorce which has an overbearing effect on their upbringing and overall wellbeing. Against this background this paper seeks to examine child custody as a measure in Islam to prevent indiscriminate divorce and to sustain the overall welfare of the children. 


\section{The Concept of Divorce in Islam}

Divorce is common across different civilisations and cultures and therefore reflects a human phenomenon. ${ }^{7}$ The prevalence of dissolution of marriage which take different conceptions, forms and styles, predated Islam. ${ }^{8}$ In Judaism, the power to divorce is only a prerogative of the husband who uses it indiscriminately; in Christendom, divorce is seriously frowned at and only allowed in such a case when one of the spouses becomes irreligious and once separated, the two remain unmarried for life; while Hinduism holds that a marriage once consummated can never be ended. ${ }^{9}$

The religion of Islam allows repudiation of marriage only as a last resort when the couple can no longer live together in love, peace and tranquility. ${ }^{10}$ Should there be a need for divorce, the couples are enjoined to conduct themselves in the whole atmosphere of loving kindness such that no love-lost relationship will rent the air and thereby the home will not turn to a hell for either or both. ${ }^{11}$ To bring about the desired-harmony in society, after every effort towards reconciliation between spouses has proved futile, the religion then permits divorce as a way to end a disturbed marriage and also introduces certain reforms into its operations.

Many reasons could serve as factors for bringing a once consummated marriage to an end. The chief among them is the desire not to live together as husband and wife again. ${ }^{12}$ As soon as this development is noticed within a family, the Holy Qur'an encourages the "people of neighbourhood" to do a number of things in preventing the severance of the cord of marriage. ${ }^{13}$

If ye fear a breach between them twain, appoint (two) arbiters, one from his family, and the other from hers....(Q.4:35). ${ }^{14}$

The above scriptural quotation allows both the husband and wife right to seek for marriage dissolution if there are cogent reasons to do so. Thus, in Islam divorce is not only a prerogative of the husband alone but in certain circumstance the wife is allowed to initiate it in all kindness. ${ }^{15}$ Islam allows repudiation of marriage yet it puts in place measures that are regarded as self-restricting, self-correcting and self- preventing that are all enveloped in the question of precluding the incidence of divorce just for the betterment of the spouses, children and the society at large that they are to be separated is better than forcing them to live together in sorrow and perdition. This is because a marital home that is devoid of love is not worthy of the name hence divorce comes in as a succor from marital wrangling and lack of peace. ${ }^{16}$

Therefore, Islam allows divorce when there is ample justification for it. However, the Holy Qur'an also establishes many mechanisms to prevent 
indiscriminate occurrence of divorce. One example is the institution of iddah (waiting period after divorce or separation) mentioned in Q.2:228 and Q.65:4. The most prominent among the aims and objectives of iddah is to effect reconciliation among the disputing parties ${ }^{17}$ even with the pronouncement of third divorce; the thrice divorced woman will have to stay and live in the same husband's house for a period of three months as evidenced in Qur'an 65:1-2.

The intent of the holy Qur'an, among other things, is to bring about a possibility of amicable reconciliation between the couple who are already separated but living together ${ }^{18}$ in the midst of every chance to re-establish marital life. Even if the two do not reconcile after the expiration of iddah, both can still remarry each other according to Q.2:230 just to show how Islam enjoins marriage to be permanent in all love, peace, harmony and tranquillity.

\section{Child Custody under Customary Courts in Oyo State, Nigeria}

Deciding cases of contentious child custody may not follow the same patterns in different places and climes since it is one of the social interactions in Islam, hence social norms of people take precedence. Over the years, different changes and developments have appeared in adjudicating contested cases of child custody in many customary courts in Oyo State, Nigeria. ${ }^{19}$

Deciding disputed cases of child custody in these localities do not make recourse to the principles and directives put in place by the shariah to safeguard uncalled for circumstances. Instead, the courts hold onto the statutory laws, customs and traditions of people and therefore this led to serious debacles due to different and conflicting rulings through attribution of absolute right to custody of the children to the father in accordance with common law. ${ }^{20}$

Moreover, in some of the customary courts, mothers are always awarded custody of female children while that of male children goes to the father. ${ }^{21}$ In others, the father has absolute right to custody of the children of the marriage and, upon his death, the right automatically becomes that of the male head of the matrilineal family. ${ }^{22}$

Four towns in Oyo state have been considered for this study, namely, Ibadan, the state capital, Oyo, Ogbomoso and Saki, which are the state's zonal headquarters with high concentration of Muslims and, thus, may be deemed as fairly representative of other towns in the state.

It has to be noted that investigations conducted at the various customary courts in the selected towns reveal similarities in the patterns of decisions taken on the decided cases that were examined. 
Firstly, it was observed that the right to child custody is awarded either to the mother or father and not to any third party regardless of his/her closeness to the couple in dispute.

Secondly, it was observed that the main factors in awarding the right to custody was the age and sex of the children, and whether special pleas are made by either of the parties in dispute.

Customarily, the custody of children six years and above in age is awarded to the father while children who are less than six years in age are given to their mothers.

In the event of verifiable and confirmed complaints by a wife against the husband, custody of children is awarded to her if the husband is found to be a regular absentee from home due to work or being highly negligent of children. However, child custody is awarded to a husband in cases where he complained and the wife was found to be negligent of her home (including children) or has even deserted the home to join another man before the divorce case is initiated and thus is guilty of child abandonment.

\begin{tabular}{|l|c|c|c|c|c|c|}
\hline \multirow{2}{*}{ Beneficiary } & \multicolumn{5}{|c|}{ Period of Survey } \\
\cline { 2 - 7 } & $\mathbf{2 0 1 3}$ & $\mathbf{2 0 1 4}$ & $\mathbf{2 0 1 5}$ & $\mathbf{2 0 1 6}$ & $\mathbf{2 0 1 7}$ & Total \\
\hline $\begin{array}{l}\text { Children granted fathers' custody } \\
\text { (based on child age) }\end{array}$ & 52 & 73 & 38 & 49 & 27 & 239 \\
\hline $\begin{array}{l}\text { Children granted mothers' custody } \\
\text { (based on child age) }\end{array}$ & 36 & 45 & 39 & 28 & 49 & 197 \\
\hline $\begin{array}{l}\text { Children granted to fathers (based on } \\
\text { pleas) }\end{array}$ & 7 & 4 & 9 & 5 & 4 & 29 \\
\hline $\begin{array}{l}\text { Children granted to mothers (based } \\
\text { on pleas) }\end{array}$ & 2 & 1 & 5 & 2 & 3 & 13 \\
\hline $\begin{array}{l}\text { Older children granted to fathers } \\
\text { (based on sameness of sex) }\end{array}$ & 6 & 3 & 5 & 4 & 7 & 25 \\
\hline $\begin{array}{l}\text { Older children granted to mothers } \\
\text { (based on sameness of sex) }\end{array}$ & 5 & 2 & 1 & 7 & 2 & 17 \\
\hline Grand Total & $\mathbf{1 0 8}$ & $\mathbf{1 2 8}$ & $\mathbf{9 7}$ & $\mathbf{9 5}$ & $\mathbf{9 2}$ & $\mathbf{5 2 0}$ \\
\hline
\end{tabular}

Below is a table showing the number of children involved in divorce cases between $2013-2017$

Source: Result of field work conducted between January 2017 and July 2017

Within the last five years $(2013-2017)$ two hundred cases of disputed child custody involving five hundred and twenty children were sampled. The verdicts of the courts were as shown in the table above. 
239 children gained the fathers' custody because the children were six years of age. 197 children were assigned to their mothers since they were less than six years of age. Another 25 older children were given to their fathers basically because they were males. 17 older children were also given to their mothers because they were female. 29 children were granted to their fathers as a result of strong pleas (in relation to the reports and complaints of waywardness, promiscuity and that the women concerned were already dating other men). The remaining 13 children went in favour of the mothers on the strength of the pleas made by their mothers, and because the men in question were irresponsible, drunkards and adulterers with no wives or female relatives who could adequately take care of the children.

\section{Implications of Islamic Marital Jurisprudence on Child Custody Cases in Oyo State Customary Courts}

Islam as a religion and a complete way of life has provision for every aspect of man's life and, if he follows it, his earthly sojourn will not be blemished but peaceful and devoid of all means that are capable of precluding his blissful life in the hereafter. Going by the various findings from different cases of disputed child custody that were decided upon in the state as shown earlier, one would notice that human nature has affected sense of judgment and, therefore, the aftermath of the verdicts in most cases presented grave consequences.

Islamic marital regulations are divine codes that are free from real and imagined weaknesses and indeed have no 'sacred interest' to protect whatsoever. Thus, the marital life of Muslims must be governed according to these faultless provisions. Nearly all the sampled cases decided in the customary courts in Oyo state did not follow the spirit of the shariah to the letter and, therefore, led to chaotic situations.

Take for instance, the 239 children granted to the fathers simply because the children were six years of age, contrary to Islamic prescriptions which entrust their care to the mothers. Hammudah opines that the care of young children remains with the divorced mother except when she becomes unfit. ${ }^{23}$ This view is also expressed by Al-Hakim when he quotes the Prophet:

A mother has every right to look after her children. The son of Abdullah has established this principle in a response which tradition has handed down to us. A woman had just been divorced by her husband, by whom she had a son. She took the child in her arms and lodged a complaint with the Prophet: "Prophet of God", she said, visibly affected, "this child is my son, my womb is the vessel that contained him, my breasts 
are the vessels whence he fed, my garment forms the cover in which I hold him wrapped up. And his father has divorced me, and wants to take away my child; he wants to separate me from my son." "To thee," said the Prophet, "belongs the right to keep that child, until thou marries again, and hast consummated the marriage." 24

However, it is the father's responsibility to look after the moral education of his children, correct them, and send them to school or to a master or mistress who may instruct them. He must also see to their circumcision. And while the mother practically nurses and cares for the children, the father should also bear the full cost of the said cares and compensate the mother for the services rendered. ${ }^{25}$ Hammudah contends further that while this may be a source of tension and litigation, it is also an avenue through which reconciliation can be effected. ${ }^{26}$

According to Doi and 'Awdatu, Muslim jurists maintain that the custody and guardianship of the child rests with the mother until seven years of age (for male) or maturity (for female). ${ }^{27}$

In case the mother remarries or becomes disqualified, Wahbah Zuhayli argues that according to the shariah the duty becomes necessary upon the children's relatives in the following order: ${ }^{28}$

i. $\quad$ Mother's mother

ii. Father's mother

iii. Mother's grand-mother

iv. Father's grand-mother

v. Full sister

vi. Uterine sister

vii. Daughter of full sister

viii. Daughter of uterine sister

ix. Full maternal aunt

x. Uterine maternal aunt

xi. Full paternal aunt

In the cases surveyed above, no proofs are adduced that the mothers were unfit when custody was granted to the fathers. Also, Islamic law maintains that if a mother becomes unfit, custodial right does not devolve on the father but on the mother's mother, father's mother, in that order. It is only in the absence of female relatives that the right becomes that of the father.

Doi further notes that in the absence of female relations the custody of the children will devolve on the male relations in the following order of priority in tandem with Islamic law: ${ }^{29}$ 
i. Father

ii. Nearest paternal grand-father

iii. Full brother

iv. Consanguine brother or any other paternal relative within the prohibited degree.

Still, in the absence of legal guardians, the Qadi or the Islamic court will appoint a guardian to protect the minor's property. The importance of early nurturing and physical custody of a child by the mother is emphasised and protected in many Islamic countries. Preserving the bond between mothers and their young children is so important that it may result in the children accompanying their mother to prison. ${ }^{30}$ In Saudi Arabia, for instance, it has been observed that nearly half the population of the Central Riyadh Woman's Prison in 1983 consisted of children under the age of seven. Another American mother, who was also imprisoned in the Kingdom during a divorce dispute with her Saudi husband in the early 1990s, also reported the number of young children who accompanied their mothers into prison. One American woman told of a Saudi woman who had been imprisoned because her husband's family accused her of infidelity when she became pregnant several months after her husband's death. The shariah court did not separate a breast-feeding infant from its mother. It was after two years that the court found the mother unfit on religious grounds and the child was taken from her. ${ }^{31}$

As regards the 197 children released to the mothers since the children were less than six years of age, it is apt to state that the decision of the courts appeared to a large extent to be in consonance with the spirit and letter of shariah, but the intent may not be the same. However, other conditions like new marriage of the mothers to another men and change of religion on the part of the mothers can debar them from having right to custody of young children.

Wahbah Zuhayli asserts further that regarding physical custody, many juristic schools hold that a new marriage of a mother must not be between her and a stranger (a non-relative) or to a relative who is not a non-mahram to the child. Only the Shafi'i school wants sameness of religion between the mother and father as a requirement before she could have physical custody of a Muslim child. Also, the Hanafi school accepts a change of religion as a factor to debar a Muslim mother's right to child custody. Jurists of the other Sunni schools hold that the mother must ensure that the child is reared in an Islamic way. ${ }^{32}$

However, the Sunni schools agree that a mother loses her right to custody if there is evidence to prove that she can adversely affect the religious understanding of the child. Among others this may include instances when she goes to church with the child; indoctrinates the child with the belief system of a different faith or 
practices the ideals and rituals of a different religion before the child. Some other conditions must also be met for a mother to have custody e.g. the mother must not raise the child in an environment hated by him/her. ${ }^{33}$ These all important factors are not all that matters in awarding custodian right to mothers in customary courts in Oyo State since the benchmark of less than six years of age of the children was already invoked.

Moreover, 25 older children went in favour of the fathers because the children were male and 17 older children were given to the mothers because the children were female. The courts adopted this decision as a result of a common belief that male children are best nurtured by their fathers with an injection of masculine traits into their lives, while for the proper inculcation of feminine characteristics in a female child, the mother should rear such a child. These verdicts ran counter to the Islamic marital jurisprudence because the sex of both the child and either of the parents do not count in awarding the right to custody but, rather, the ability to take proper care of the child by either of the parents. In taking charge of the education and general well-being of the children of a divorced couple certain conditions which relate to the guardians must be fulfilled; otherwise the right of custody of such a guardian ceases. The conditions as laid down by the shariah in Islam according to Wahbah Zuhayli are the following: ${ }^{34}$

i. He/she must be sane, soft and not wicked.

ii. Must possess the ability of looking after the child in such a way that he/she is of middle age and not very old. This provision may debar the mother's grandmother and father's grandmother from having the custody of a child.

iii. His/her accommodation and environment must be free from exposing the child to bad characters and loss of property.

iv. He/she must be of impeccable character and free from contagious diseases.

v. He/she must be truthful with regards to the child's property.

He also observes that the guardian should be of the same faith as the child to prevent the possibility of conversion to other faith. A male guardian must of necessity possess a family capable of looking after the child. A newly married woman forfeits her chance to custody as a result of her new role in the house of her husband which may not allow her to take proper care of the child. When a woman forfeits her right to custody of her child by reason of her new marriage to another man, the right does not devolve on her again after dissolution of that marriage. At the tender age of upbringing, Islam favours mothers to have custodial right unless she becomes disqualified. Therefore, awarding custodial 
right on the basis of the sameness of the sex of both the child and either of the parents does not hold, because the child may end up not being properly maintained.

The other 29 children and the remaining 13 were decided based on the strength of the pleas emanating from the fathers and mothers respectively. Here, the allegations from both sides of the parents against each other influenced the decisions of the courts. The instruments used in deciding the above 42 cases to a very significant extent agrees with the spirit of the shariah. According to Wahbah Zuhayli, the presence of claims like various accusations contained in this case may warrant a parent to lose his/her custodian right if upon serious investigation it is established that the alleged parent is guilty.

It can be deduced from the foregoing exposition that the shariah is all about according human beings respect and ensuring peaceful co-existence in all conditions. Yet out of 520 children involved in 200 cases of disputed child custody sampled for this study, only 42 of them ( $8 \%$ of the sampled population) appear to have been awarded to the most qualified parents.

Arising from the above, it can be conveniently stated that the particular parent, together with his/her family members, who loses rights of custody upon the strength of the allegations levelled against him/her would reasonably accept the decision of the court and see no reason for fomenting trouble This is unlike when the decision of the court is based on the sameness of the sex of the child and either of the parents or when the age of a child is six or less. This therefore suggests that following Islamic jurisprudential provisions in awarding right to custody of children will prevent rancorous situations and allow all concerned to live together with desired peace, love and kindness, whatever be the circumstance.

\section{Custody of a Child after Divorce}

In the event of divorce, children often bear the most painful consequences. ${ }^{35}$ Islamic law takes their needs into account and makes sure that they are cared for. The financial support of children - both during marriage and after divorce - rests solely with the father. ${ }^{36}$ This is the children's right upon their fathers, and courts have the power to enforce child support payments, if necessary. The amount is open to negotiation and should be in proportion with the husband's financial means. ${ }^{37}$

Qur'an 2:233 advises the husband and wife to consult each other in a fair manner regarding their children's future after divorce. Also, this verse specifically holds that infants who are still at nursing stage may continue to 
breastfeed until both parents agree on the period of weaning through 'mutual consent and counsel'.

Islamic law stipulates that physical custody of the children must go to a Muslim who is in good physical and mental health, and is in the best position to meet the children's needs. Different jurists have established various opinions on how this might best be done. Some have ruled that custody is awarded to the mother if the child is under a certain age, and to the father if the children is older. Others allow older children to express a preference. Generally, it is recognised that young children and girls are best cared for by their mother. ${ }^{38}$

To provide needed female care for the infant, Wahbah Zuhayli observes that all the juristic schools ascribe first preference to a mother's claim to physical custody of her young child so long as she meets the prescribed conditions for a female custodian. The father is required by law to provide for the mother's finances while she is taking custody of the divorced father's child. However, the duration of female custody lapses once the child attains a certain age of custodial transfer. ${ }^{39}$

The Hanbali and Shafi' $i$ schools do not differentiate between girls and boys concerning the period of female custody. The Hanbalis hold that the female custodian should be given custody from birth till the child attains the age of seven, at which point he or she may choose between parents. The Shafi"is allow female custody up till the child attains the age of puberty and can choose either parent as custodian. The Malikis express that female custody of a boy extends till he attains age of discretion and for a girl till she marries. With the Hanafi school, female custody of a boy ends when the child can feed, clothe, and cleanse himself. The majority of Hanafi jurists put the age of discretion at seven years while others put it at nine. Hanafi jurists disagree on the duration of a mother's custody of her female child. The majority believe that the mother's custody ceases when the girl attains maturity, which is nine or eleven years of age. However, others permit the mother's custody to remain until the girl attains the age of marriage..$^{40}$ The school does not therefore attach a particular age of custodial transfer.

Since there are differences of opinion among Islamic scholars on child custody, one might find variations in local laws. In all cases, however, the main concern is that children are cared for by a fit parent who meets their emotional and physical needs. ${ }^{41}$ Therefore, while deciding the cases of contested child custody in the customary courts of Oyo State, Nigeria, the welfare, wellness, upbringing, education, protection and interest of the children must be considered while every ulterior motive must be done away with. 


\section{Adoption in Islam}

Islam does not sanction adoption of a child as a practice for mankind due to its harmful effects on the society. The shariah recognises the paternity of a child through legal marriage contract and therefore rejects legal adoption of a child outside biological fatherhood. According to Islamic law, the actual status and rights enjoyed by a biological child will never be conferred on an adopted child; he is and continues to remain the real child of his original biological father ${ }^{42}$ " $\ldots$ nor has He made your adopted sons your sons..." Q.33:4.

The Holy Qur'an in chapter 33:4-5 stipulates that adopting a child does not in any way affect the status quo though, because of deep love, one may want one's adopted child to become one's real son or daughter. This is just a wish which cannot be realistic; an adopted child remains a child through adoption and can never become one's real child. Moreover, in order not to cause confusion as regards fatherhood of the adopted child, the Qur'an enjoins Muslims to call them by the name of their real father "...call them by after their fathers..." and that is better and most just inasmuch as adoption can never bring about a natural parent - child relationship and it is incapable of transferring genetic features from an adopted father to his adopted sons or daughters.

Legal adoption is banned in Islam. According to Islamweb.net, the following are some of the reasons for it:

- It falsifies the natural setting of society and reality.

- It blocks the legitimacy and paternity of a child.

- It deprives the deserving heirs of their lawful and rightful shares of the property left behind by their dead father.

- It leads to deception because it involves taking a stranger into a family where he is not a bona fide member and be in privacy with women who are his non-marriageable relatives and, therefore, in a way affects marriage relationships in Islam. ${ }^{43}$

However, it is allowed in Islam to look after an orphan, clothe, feed, educate him and provide for all his basic daily needs so that he will not feel alienated from society or weighed down by the death of his biological father. This is regarded as a meritorious act in the word of the glorious Qur'an, chapter 2:220, which advocates taking care of the affairs of orphans in the best way and without ascribing to them the status and rights of one's biological children, for the Qur'an refers to them as brethren, not real children. With this, Islam has basically defined the line of family lineage without an alien element entering into it. ${ }^{44}$ 


\section{Conclusions and Recommendations}

An attempt has been made in this paper to explore some salient issues on the implications of al-hadanah in Islamic marital jurisprudence. Therefore, the paper concludes that despite noticeable differences among Sunni schools concerning child custody, the law is capable of bringing about reconciliation between disputing parties and thus it is a measure in disguise to safeguard indiscriminate severance of the cord of marriage in Islam. This is because rendering assistance, especially financial, as part of the law to a divorced wife on account of taking care of the child of the divorced husband unavoidably brings the two together and may bestow again on them the natural feelings of love, affection and sympathy that were once lost between them. This does not mean that it may not lead to practices contrary to Islam if not done with the utmost fear of Allah. The basic consideration for deciding child custody cases in customary courts in Oyo State Nigeria must be the well-being, education, training, protection, overall welfare and general interest of the child and that adoption in its various forms and types is forbidden, for it stands as antithetical to what Islam represents.

Finally, the study makes the following recommendations:

- Further studies should be carried out in other states of Nigeria to assess the implications of al-hadanah in Islamic marital jurisprudence to avoid heated crises within Muslim families and to educate the faithful as to why shariah should dictate every practice of their existence.

- Physical custody of Muslim children after separation must be granted to a Muslim who is sane and healthy and is in the best position to provide for the children's religious and social needs.

- The Supreme Council for Islamic Affairs (SCIA) as the apex Muslim religious body in Nigeria should persuade the nation's judiciary through the federal government to enact and enforce law that will allow everybody in the Nigerian courts to be treated in accordance with his/her religious personal and family laws inasmuch as freedom of religion is entrenched in the constitution of the Federal Republic of Nigeria.

- The custody of a child is her/her sole right and not of that either of the parents. Thus, while deciding disputed cases of child custody in court, the wishes, security and betterment of the child must matter most.

- Muslim parents should not allow their wards to be adopted children by people of other faiths irrespective of their relationship, for fear of a possible conversion. 


\section{Notes}

* Aminullahi A. Yusuff is a lecturer in the Department of Islamic Studies, Federal College of Education (special), Oyo, Oyo State, Nigeria. He holds M.A. in Islamic Studies. Email: aminullahiadetoro@gmail.com.

1. Saalih A. Ghaanim, Marital Discord (al-Nushooz) (Riyadh: Al-Basheer Publications and Translations, 1993), 11.

2. Abdullah Y. Ali, The Holy Quran English Translation of the Meanings and Commentary (India: Sh. Muhammad Ashraf Publishers, 1934), 214.

3. Ghaanim, Marital Discord, 11

4. Ibid.,12.

5. Abdur Rahman I. Doi, Shari 'ah The Islamic Law (London: Ta Ha Publisher, 1984), 168.

6. Abd al'Ati. Hammudah, The Family Structure in Islam (Maryland: American Trust Publications, 1977), 245-8.

7. Hammudah, The Family Structure, 246.

8. Ibid., 217.

9. Ibid., 218.

10. Maulana M. Ali, The Religion of Islam: A Comprehensive Discussion of the Sources, Principles and Practices of Islam (New Delhi: S.Chand \& Company Ltd, n.d.), 671.

11. Abdur Rahman I. Doi, Shari 'ah The Islamic Law, 80 .

12. Ali, The Religion of Islam, 273.

13. Ghaanim, Marital Discord, 55.

14. Yusuf Ali, The Holy Quran, 220.

15. Hammudah, The Family Structure, 243.

16. Ali, The Religion of Islam, 273.

17. Abdur Rahman I. Doi, Women in Shari'ah (Islamic Law) (London: Ta Ha Publisher, 1989), 95.

18. Hammudah, The Family Structure, 235.

19. Akintunde Esan's Legal Illumination, Custody of a Child: What the Court will consider in Awarding Custody of Children in Nigeria, Available at: https:// akintundeesan.blogspot.om $>$ cus.... (Accessed on: 22/3/2018).

20. Ask Nigeria, Child Custody in Nigeria, Available at: asknigeria.com.ng $>$ legal system. (Accessed on: 22/3/2018).

21. Mz Agams, Child Custody in Nigeria. Available at: https://mzagams.wordpress. com > child-c.... (Accessed on: 22/3/2018).

22. Be Oniha, Dissolution of Marriage and Custody of Children under Customary Law in Nigeria. Available at: edojudiciary.gov.ng $>$ uploads $>201 \ldots$ (Accessed on: 22/3/2018).

23. Hammudah, The Family Structure, 246.

24. Al-Hakim, Al-Mustadraka 'alaș Sahihayn (Bayrut: Dar-l kutubi 1-'ilmiyyah), 1990), vol. 22, Hadith no: 2830.

25. Abdur Rahman I. Doi, Shari 'ah The Islamic Law, 206. 
26. Hammudah, The Family Structure, 246.

27. Abdur Rahman I. Doi, Shari' ah The Islamic Law, 214. 'Awdatu -1 - 'Awayishah Husayn, Al-Mawsu'atu' l - fiqhiyyatu'l Muyassarah (Jordan: Al-Maktabatul Islamiyyah, 2005), vol. 5, 413-20.

28. Wahbatu Zuhayliyy, Al-Fiqhul Islamiyyu wa'adillatuhu (Damascus: Darul Fikir, 2001), vol. 10, 44-7.

29. Abdur Rahman I. Doi, Shari 'ah The Islamic Law, 215.

30. Uhlman U. Kristine, Overview of Shari'ah and Prevalent Customs in Islamic Societies - Divorce and Child Custody. Available at: www.expertlaw.com/ library/family_law. (Accessed on: 10/1/2015).

31. Ibid.

32. Zuhayliyy, Al-Fiqhul Islamiyyu, 49-53.

33. Ibid., 44.

34. Ibid., 49-55.

35. Aisha B. Lemu, Islamic Studies for Senior Secondary School Book Two, 203.

36. Abdur Rahman I. Doi, Women in Shari'ah, 102.

37. Abdur Rahman I. Doi, Shari 'ah The Islamic Law, 206.

38. Kristine, Overview of Shari 'ah.

39. Zuhayliyy, Al-Fiqhul Islamiyyu, 44

40. Kristine, Overview of Shari 'ah.

41. Ibid.

42. Adoption in Islam. Available at: www.islamweb.net/..../adoption-in-islam. (Accessed on: 25/3/2015).

43. Ibid.

44. Ibid. 